Egyptian Journal of Rabbit Science, 29 (2): 197- 217 (2019)

\title{
IMPACT OF ADDING CITRIC, LACTIC ACIDS AND PROPYLENE GLYCOL ON : 2- REPRODUCTIVE PERFORMANCE OF BUCK AND DOE RABBITS
}

\author{
A. A. Sedki; Samia, M. Mobarez and Noha, M. Abd El-Azeem \\ Animal Production Research Institute, Agriculture Research Center, Dokki, Egypt \\ e.mail:Sedki64@hotmail.com
}

Two experiments were designed on buck and doe rabbits. In the $1^{\text {st }}$ experiment, a total of $25 \mathrm{NZW}$ rabbits bucks $(9$ months of age with a mean live body weight of $3400 \pm 173 \mathrm{~g}$ ) were allotted into 5 treatments to study the effect of citric, lactic acids and propylene glycol on nutrients digestibility coefficients, blood picture, sexual urge, physical semen and spermatozoa characteristics, feed intake and live body weight changes. In the $2^{\text {nd }}$ experiment, a total of 40 nulliparous does (8 months of age with an average live body weight of $3100 \pm 188 \mathrm{~g}$ ) were allotted into 5 treatments. Does were inseminated with semen from untreated bucks. Does performance including:- blood picture, litter size and weight at birth and at weaning, milk yield, feed intake and body gain were studied.

First group in both experiments received plain water and severed as a control group, while water for the $2^{\text {nd }}, 3^{\text {rd }}, 4^{\text {th }}$ and $5^{\text {th }}$ groups for the two experiments supplemented with citric, lactic acids (Concentration of citric and lactic acid 98\%) or propylene glycol (2\% propylene glycol, as an energy source) at $0.5 \mathrm{ml} /$ liter drinking water and mixture of them with 0.75 $\mathrm{ml} /$ iter at $0.25 \mathrm{ml}$, each, respectively.

Results of the first experiments indicates significant improvements in buck's nutrients digestibility of DM, OM, CP and NFE with the mixture of citric, lactic acid and propylene glycol followed by citric acid group compared to other groups. There was no significant treatment effect on CF and EE digestibility coefficient. Hematocrit, red blood cells' counts and white blood cells counts increased significantly in all treated groups compared to control while hemoglobin values, increased significantly in all treated group (except lactic acid group) than control. Total protein, globulin, triiodothyronine and testosterone, were significantly increased 
due to supplemented of citric, lactic acids, propylene glycol individual or a mixture of them compared to the control group.

Significantly improvements in each of sexual urge (libido) and all the semen and sperm characteristics in treated group compared to control group. In second experiments does performance with improved using individual citric, lactic acids or propylene glycol the mixture of them in drinking water compared to control. Hematocrit, red blood cells' counts, white blood cells counts and triiodothyronine increased significantly in all treated groups compared to control. Hemoglobin values were significantly higher in all treated group (except lactic acid group) than control. Total protein, albumin, globulin and $A / G$ ratio significantly affected by supplemented citric, lactic acids or propylene glycol and mixture of them was higher in group received propylene glycol or group received mixture of them. The changes in weight gain of does in the four groups across the experimental period were significant in citric acids or propylene glycol group. organic acids or propylene glycol supplemented groups achieved improvement in litter weight at birth. At weaning day, all treated groups had heavier kits' weight than those in control. Litter size increased significantly due to supplementing drinking water with citric, lactic acids or propylene glycol and mixture of them than that in control group during the all experimental days. Mortality rate reduced in tested groups compared to the control. Milk yield in $3^{\text {rd }}$ week of lactation was increased significantly in all treated group compared to control.

In conclusion, this study demonstrated the effectiveness of citric acid, lactic acid and propylene glycol and its ability to improve reproductive performance as a result role for additives in improved blood metabolites and improving available energy, improving nutrition digestion as well as improving milk quality.

Key words: Rabbits, reproductive performance, organic acids, propylene glycol.

One of the main goals of small, medium and large farms is to improve the reproductive performance of rabbit does. A better nutritional status of both fetuses and suckling kits has a positive effect on their later productivity. Intensive reproductive rhythm creates a negative energy balance in does, they are unable to 
consume enough feed (energy) for the nutritional requirements of fetus and lactation, and therefore lose most of their fat reserves. Furthermore, nulliparous does also expend energy because they are still growing (Szendro et al, 2012).

Rabbits in modern farms are subject to intensive breeding rhythms. Females are high milk producers and energy expenditure due to significant conflict between lactation and gestation. This situation has lead to a negative energy balance especially with the mobilization of body fat in primiparous doe rabbits. Poor body condition and poor health seriously affects the reproductive characteristics i.e. fertility rate and lifespan of the doe, as well as, ovarian physiology (Lorenzo, 2014).

There is a relationship between nutrition and productivity, which greatly affects the production and reproductive performance of rabbits. The effect on sperm production, sexual and sperm quality, is significantly altered with age, nutrition, environment, health, drugs and chemicals. There was a high correlation between age, body weight, and buck semen quality (Oloyede, 2018). Organic acids supplementation improves the utilization of dietary nutrients in the gastrointestinal tract of broilers. Moreover, organic acids can reduce the toxic metabolites, colonization of pathogens and endocrine changes in the animal's body during heat stress observed in citric acid supplemented in broiler feed (Abdel-Fattah et al., 2008). The supplementation of organic acids improves the bioavailability of protein and uptake of minerals like magnesium, calcium, phosphorus and zinc (Hinton et al., 1988). Organic acids such as fumeric acid, citric acid, formic acid etc. have been used as growth promoters to enhance the digestibility of feed. Supplementation of organic acid can also improve milk quality. Feeding of orange extract reduced somatic cell count in high producing cows during moderately to hot summer season (Soderstrom, 2012). Oloyede, et al. (2018) found that inclusion of 3\% citric acid in the diet of the rabbit bucks supported normal growth of the reproductive tract and semen quality of the rabbit bucks.

The energy deficit caused by milk production is responsible for intense body mobilization and reduced reproductive performance. This situation is exacerbated in primiparous rabbit does since their feed intake capacity is not fully developed and their growth is not complete (Fortun-Lamothe et. al.,1999; Xiccato et al., 2004). Energy deficit is therefore closely linked to reduced lifespan of reproductive females because the main reasons for culling in rabbit breeding units is infertility or poor body conditions. Several strategies concerning rearing, 
feeding, management of reproduction or litters and genetics, could permit a better management of the nutritional demands and contribute to an improvement of lifespan of the does (Fortun-Lamothe, 2006).

Grummer, (2008) stated that the addition of propylene glycol (in cows) can be converted to propionic acid in intestines are transported to the liver where it is converted to glucose, although the glycoprotein pathway. Some researchers have shown that the addition of propylene glycol could increase milk production has been reported (Lucci et al., 1998) in addition, reproductive efficiency has improved in cow (Miyoshi et al., 2001). Propylene glycol may improve available energy, offering beneficial effects, especially environments of high temperature and humidity.

Therefore, the objective of the present work aim to evaluate the effect of some water supplements as organic acids and propylene glycol on nutrient digestibility of bucks and the physiological, reproductive and productive performance on rabbits bucks and does.

\section{MATERIALS AND METHODS}

This study was carried out at a private rabbitry in Dakahlia governorate. Two experiments were conducted to evaluate the influence of supplementing individual citric, lactic acids, propylene glycol or mixture of them to drinking water on productive and reproductive performance of rabbits' bucks and does.

\section{Experimental animals:}

Experiment 1: Twenty-five New Zealand White (NZW) rabbit's bucks 9 months old with an average weight $3400 \pm 173 \mathrm{~g}$ were assigned to five experimental groups (5 bucks each). Bucks were randomly placed in individual wire cages. Experiment 2: Forty (NZW) rabbits does (8 months old with an average live body weight $3100 \pm 188 \mathrm{~g}$ ) were allotted into 5 treatments ( 8 does each).

\section{Feeding and water treatments}

All rabbits were fed ad libitum on pelleted ration. Ingredients and chemical composition of the basal ration are summarized in Table 1. First group in both experiments received plain water and severed as control group, while water for the $2^{\text {nd }}, 3^{\text {rd }}, 4^{\text {th }}$ and $5^{\text {th }}$ groups for the two experiments supplemented with $0.5 \mathrm{ml} /$ liter of citric (T1), lactic acids (T2) citric and lactic concentration $98 \%$ and propylene glycol (T3) and $0.75 \mathrm{ml} /$ liter mixture of them (T4). 


\section{Digestibility trails:}

Three bucks of each experimental group were chosen and put into the metabolic cage to determine the digestibility coefficients of nutrients. The chemical analyses of the basal diet and feces were carried out according to AOAC (1996). Rabbits are individually placed in metabolic cages with wire bottoms to collect feces. Feces were collected, and the sample was dried at $60^{\circ} \mathrm{C}$ for 48 hours, and stored for consequent proximate chemical analyses.

\section{Measurements and technical procedures:}

First experiments:

Bucks libido (sexual desire) was estimated as described by Daader et al., (1999 a \& b). Reaction time (recorded from the moment of mounting the doe by the buck and completes ejaculation by using stop watch). Semen collection was collected twice a week from each buck by artificial vagina. Semen physical characteristics (color, ejaculate volume, sperm concentration $\times 10 \% \mathrm{ml}$ and total sperm number/ejaculate), were determined.

The collected semen sample was analyzed for semen quality parameters such as semen volume, sperm concentration, live sperm percentage, sperm motility and abnormal sperm percentage as reported by Ahemen et al. (2013). Also, spermatozoa characteristics (mass and progressive motility were estimated. Dead and live spermatozoa percentage was determined according to Campbell (1956).

\section{Second experiments:}

Does were inseminated with semen from untreated bucks for one parity. Mating of does was executed twice by bucks of proven fertility. Pregnancy was diagnosed by abdominal palpation at 12 days after service. Does failed to conceive were immediately re-mated. Performance of does including, blood picture, litter size (LS) and weight (LW) were recorded at birth and at weaning (4 weeks). Milk yield (MY) was estimated at the $3^{\text {rd }}$ and $4^{\text {th }}$ weeks of offspring age. Mortality rate for offspring was estimated from birth to weaning.

At the end of the two experiments blood samples $(3 \mathrm{ml})$ were withdrawn at morning from marginal ear vein for each treatment group from 3 bucks and 3 does each group before access feed and water.

Blood samples were centrifuged at 3000 r.p.m for 15 min to obtain a clear serum samples and stored at $-20{ }^{\circ} \mathrm{C}$ until analysis the following parameters: 
plasma total protein (TP, g/dl), albumin (Alb, g/dl) were executed by using kits of Stanbio Laboratory Inc, procedure No. 0280. (San Antonio, Texas, USA).

Table 1: Ingredients and proximate chemical composition of the basel diet.

\begin{tabular}{lc}
\hline Items & $\mathbf{\%}$ \\
\hline Ingredients & 15.0 \\
Wheat bran & 23.0 \\
Clover meal (12\%) & 22.0 \\
Barely & 1.25 \\
Ground bean straw & 15.0 \\
Yellow corn & 20.0 \\
Soybean meal (44\%) & 1.45 \\
Molasses & 0.40 \\
Di Calcium Phosphate & 1.0 \\
Limestone & 0.5 \\
Sodium chloride & 0.3 \\
Vitamins \&minerals premix* & 0.10 \\
DL- Methionine & $\mathbf{1 0 0}$ \\
\hline Total & \\
\hline Calculated analysis* & 2622 \\
Digestible energy (DE),kcal/kg & 18.01 \\
Crude protein (CP), \% & 12.25 \\
Crude fiber (CF), \% & 0.91 \\
Calcium (Ca), \% (P), \% & 0.517 \\
Total Phosphorus (P), & 0.951 \\
L-Lysine, \%
\end{tabular}

*Vitamins and minerals premix supplied per kilogram diet contains: Vit. A, 6000 IU; Vit. D, 900 IU; Vit. E, 40 mg; Vit. $\mathrm{K}_{3}, 2$ mg; Vit. $\mathrm{B}_{1}, 2 \mathrm{mg}$; Vit. $\mathrm{B}_{2}, 4 \mathrm{mg}$; Vit. $\mathrm{B}_{6}, 2 \mathrm{mg}$; Vit. $\mathrm{B}_{12}$, $10 \mu \mathrm{cg}$; Nicotinic acid, $50 \mathrm{mg}$; Biotin, $50 \mu \mathrm{cg}$; Folic acid, $10 \mathrm{mg}$; Choline, $250 \mathrm{mg}$; Zinc, 50 mg; Manganese, 8.5 mg; Iron, 50 mg; Copper, $5 \mathrm{mg}$; Iodine, $0.2 \mathrm{mg}$; Selenium, $0.1 \mathrm{mg}$; and Cobalt, $0.1 \mathrm{mg}$.

*These values were calculated according NRC (1977)

Globulin concentration ( $\mathrm{Glb}, \mathrm{g} / \mathrm{dl}$ ) was calculated by subtracting Alb values from TP values. Activities of aspartate aminotransferase (AST) and alanine aminotransferase (ALT), were determined calorimetriclly using kits supplied by Sentinel Ch. SpA- Via Robert Koch, 2-20125 Milan- Italy. Blood plasma triiodothyronine $\left(\mathrm{T}_{3}, \mathrm{ng} / \mathrm{ml}\right)$ was determined by radioimmunoassay technique with commercial kits produced by the Diagnostic Products Corporation (DPC), Co. Los Angeles, USA. Testosterone concentrations in plasma were measured 
by a simple solid phase enzyme immunoassay utilizing horseradish peroxidase as a tracer (Equipar, Via G. Ferrari, Saronno, Italy).

Statistical analysis:

Data were subjected to the analysis of variance using General Linear Model (GLM) of SAS (2006). One-way analysis of variance was carried out using the following model:

$$
\mathrm{Y}_{\mathrm{ij}}=\mu+\mathrm{T}_{\mathrm{i}}+\mathrm{e}_{\mathrm{ij}}
$$

Where $Y_{i j}=$ Any individual observation, $\mu=$ Overall mean, $T_{i}=$ The effect of treatments $(i=1 \ldots, 4), e_{i j}=$ The experimental random error. Differences between treatment means were separated by using Duncan's multiple rang test (Duncan, 1955).

\section{RESULTS AND DISCUSSION}

\section{Bucks performance \\ Digestibility trait:}

The effects of treatment groups on nutrient digestibility coefficients in bucks are presented in Table 2. The digestibility coefficients of DM, OM, CP and NFE were significantly increased with supplementing the mixture of citric , lactic acid and propylene glycol, followed by citric acid group compared with the other groups. There was no significant effect on $\mathrm{CF}$ and EE digestibility coefficients. Digestibility of crude protein was significantly improved by 6.8 , $3.8,2.8$ and $7.5 \%$ in supplemented citric acid, lactic acid, propylene glycol and the mixture of them, respectively over the control. Being an organic acid, citric acid may weaken the structure of crude fiber thus making crude protein and phytate associated with them more susceptible for enzymatic digestion and facilitate the nutrient digestibility. These results are in agreement with Uddin et al., (2014) who found that adding citric acid (0.5\% in rabbit feed) improved nutrient digestibility. Also, Debi et al., (2010) and Romero et al., (2011) found that nutrient digestibility improved with supplemented rabbit feed with citric acid. On the other side, Kishawy et al., (2018) found that there was no positive effect on nutrient digestibility due to citric acid addition to rabbit diets.

Citric group or mixture between citric, lactic acid and propylene glycol group could influence caecal utilization of crude protein (CP) and dietary urea by influencing caecal fermentation. This effect is probably mediated by 
Sedki et al.

ammonia binding (Chrenková, 2012) thus may participate to improve nutrients digestibility coefficients.

Table 2: $\mathrm{LSM}^{*}$ of nutrients digestibility coefficients of NZW rabbits bucks as affected by studied water supplements.

\begin{tabular}{lcccccc}
\hline \multirow{2}{*}{ Parameters } & \multicolumn{5}{c}{ Treatment groups } & \multirow{2}{*}{ S. E } \\
\cline { 2 - 6 } & Control & T1 & T2 & T3 & T4 & \\
\hline DM & $65.5^{\mathrm{ab}}$ & $66.2^{\mathrm{a}}$ & $64.8^{\mathrm{b}}$ & $64.6^{\mathrm{b}}$ & $66^{\mathrm{a}}$ & 0.31 \\
$\mathrm{OM}$ & $73.9^{\mathrm{b}}$ & $76.6^{\mathrm{ab}}$ & $75.6^{\mathrm{ab}}$ & $73.8^{\mathrm{b}}$ & $75.5^{\mathrm{a}}$ & 2.1 \\
$\mathrm{CP}$ & $70.6^{\mathrm{b}}$ & $75.4^{\mathrm{a}}$ & $73.3^{\mathrm{ab}}$ & $72.6^{\mathrm{ab}}$ & $75.9^{\mathrm{a}}$ & 3.2 \\
$\mathrm{CF}$ & 50.4 & $51.4^{\mathrm{b}}$ & 51.9 & 51.6 & 52.3 & 3.5 \\
$\mathrm{EE}$ & 60 & $60.1^{\mathrm{a}}$ & 61 & 60.5 & 61.4 & 2.5 \\
NFE & $77.3^{\mathrm{b}}$ & $80.5^{\mathrm{a}}$ & $79.1^{\mathrm{ab}}$ & $80.4^{\mathrm{a}}$ & $81.0^{\mathrm{a}}$ & 1.1 \\
\hline
\end{tabular}

a,b,c: Means within the same row with different superscripts are significantly differ.(P $\leq 0.05)$.

T1=Citric $(\mathrm{Ci}) \mathrm{T} 2=$ Lactic acid $(\mathrm{La}) \mathrm{T} 3=$ Propylene glycol $(\mathrm{Pg}) \mathrm{T} 4=\mathrm{Ci}+\mathrm{La}+\mathrm{Pg}$

*LSM: Least square means, SE: Standard error

Blood biochemical constituents:

Effects of adding organic acids citric, lactic, or propylene glycol and their combination on hematocrit value $(\mathrm{Ht}, \%)$, hemoglobin concentration $(\mathrm{Hb}, \mathrm{g} / \mathrm{dl})$, total red blood cells $\left(\mathrm{RBCs}, 10^{6} / \mathrm{mm}^{3}\right)$ and total white blood cells $\left(10^{3} / \mathrm{mm}^{3}\right)$ and differential white blood cells of bucks rabbits are illustrated in

Tables 3. Hematocrit value of bucks ranged between $30.93-35.41 \%$. These hematocrit values were within the normal range (29.4 - 41.5\%) as reported ElKholy (2003). All treated group increase significantly compared to control the increase in hematocrit values may be a result of the reduced stress on the animal through good utilization of feed (Noha, et.al, 2006).

Hemoglobin concentration $(\mathrm{Hb}, \mathrm{g} / \mathrm{dl})$ of rabbits ranged between (12.49$10.73 \mathrm{~g} / \mathrm{dl}$ ) which agree with that reported by Ashour (2001). The results indicate that the hemoglobin concentration increased significantly $(\mathrm{P} \leq 0.05)$ by the supplementation of citric acids, propylene glycol and their combination over the control group. Red blood cells count (RBCs $\times 10^{6} / \mathrm{mm}^{3}$ ) of rabbits ranged between $4.1 \times 10^{6} / \mathrm{mm}^{3}$ for control group and $4.51 \times 10^{6} / \mathrm{mm}^{3}$ for propylene glycol group. Red blood cells count increased significantly $(\mathrm{P} \leq 0.05)$ in most treated group 
IMPACTOFADDINGCITRIC,LACTICACIDS \&PROPYLENEGLYCOLONRABBITS 205

compared to control. Total white blood cells (WBCs) count of rabbits ranged between $26.28 \times 10^{3} / \mathrm{mm}^{3}$ for control group and $31.60 \times 10^{3} / \mathrm{mm}^{3}$ in mixture group. The $\mathrm{Ht} \%, \mathrm{Hb}, \mathrm{RBCs}$ and WBCs increased in supplemented groups as reported here, where all these parameters improved significantly compared to control and almost with no significant differences between the supplemented groups. These improvements can be due partially to the increase of animal resistance to any physiological or environmental stress that may be due to improved utilization of feed, which has been reflected in improved performance.

Total protein, albumin and globulin were increased in supplemented groups compared to the control. Liver aminotransaminase enzymes (AST) and (ALT) activities were not significantly affected by treatments. Ashour et al (2017) showed that supplementing Synertox (mainly citric and lactic acid) in drinking water hold no negative effects on liver and kidney functions.

Supplementing individual citric, lactic acids, propylene glycol or mixture of them to drinking water increased blood plasma level of triiodothyronine $\left(\mathrm{T}_{3}\right)$. The latter is the active form of thyroxin hormone. Increasing thyroid activity asserted the biological role of organic acids and propylene glycol supplementation in activities metabolic functions and biosynthesis of hormones (Table 3). By the way, the improvement in the performance due to enhancement in thyroid activity may be related to, and explain the increase in leukocytes populations mainly lymphocytes as affected, especially by thyroid hormone (Bachman and Mashaly, 1986). Results presented in Table 3 show the changes in plasma testosterone concentration ( $\mathrm{ng} / \mathrm{ml})$ as affected by supplementing individual citric, lactic acids, propylene glycol or mixture of them to drinking water. Testosterone level was significantly $(\mathrm{P} \leq 0.05)$ higher in citric acid group, lactic acid group and mixture group of (citric, lactic acids and propylene) by 53, 63.5 and $70 \%$ over the control group, respectively. The blood testosterone concentration in treated groups was higher than in the control. The beneficial effect of the organic acids or propylene glycol additives might be due to a stimulatory effect of nutrients made available to the animal on testicular steroidogenesis, as improved nutrition enhances testicular functions, stimulating testosterone synthesis (Attia and Kamel, 2012).

\section{Semen characteristics:}

Supplemented bucks' drinking water with individual citric, lactic acids, propylene glycol or mixture of them significantly improved libido urge of bucks, in terms of less time before ejaculation compared to the control (Table 4). It was 
found that the reaction time decreased significantly in all treatments compared to control. On the other hand, no significant differences were found between treated groups in reaction time. The previous effect may be due to increased testosterone

Table 3 : LSM* of some blood parameters of NZW rabbits bucks as affected by studied water supplements.

\begin{tabular}{|c|c|c|c|c|c|c|}
\hline \multirow{2}{*}{ Parameters } & \multicolumn{5}{|c|}{ Treatment groups } & \multirow{2}{*}{ S.E } \\
\hline & Control & T1 & T2 & T3 & T4 & \\
\hline Hematocrit \% & $30.9^{c}$ & $31.9^{b}$ & $34.6^{\mathrm{a}}$ & $34.9^{\mathrm{a}}$ & $35.4^{\mathrm{a}}$ & 0.3 \\
\hline Hemaglobin g/dl & $10.7^{\mathrm{b}}$ & $12.3^{\mathrm{a}}$ & $11.9^{\mathrm{ab}}$ & $12.4^{\mathrm{a}}$ & $12.4^{\mathrm{a}}$ & 0.02 \\
\hline RBCs $10 \% / \mathrm{mm}$ & $4.1^{\mathrm{c}}$ & $4.3^{\mathrm{b}}$ & $4.4^{\mathrm{ab}}$ & $4.5^{\mathrm{a}}$ & $4.4^{\mathrm{ab}}$ & 0.7 \\
\hline WBCs $10^{3} / \mathrm{mm}$ & $26.3^{\mathrm{b}}$ & $29.9^{\mathrm{a}}$ & $29.2^{\mathrm{a}}$ & $31.2^{\mathrm{a}}$ & $31.6^{\mathrm{a}}$ & 1.1 \\
\hline Lymphocytes \% & $55.3^{\mathrm{b}}$ & $55.2^{\mathrm{b}}$ & $62.5^{\mathrm{a}}$ & $64.7^{\mathrm{a}}$ & $64.0^{\mathrm{a}}$ & 1.02 \\
\hline Neutrophils \% & $38.1^{\mathrm{a}}$ & $38.0^{\mathrm{a}}$ & $31.9^{\mathrm{b}}$ & $29.7^{\mathrm{b}}$ & $30.0^{\mathrm{b}}$ & 0.1 \\
\hline Monocytes\% & $3.6^{\mathrm{a}}$ & $3.7^{\mathrm{a}}$ & $2.4^{\mathrm{b}}$ & $2.5^{\mathrm{b}}$ & $3.2^{\mathrm{a}}$ & 0.1 \\
\hline Basophils\% & $1.7^{\mathrm{a}}$ & $1.7^{\mathrm{a}}$ & $1.6^{\mathrm{a}}$ & $1.5^{\mathrm{a}}$ & $1.0^{\mathrm{b}}$ & 0.2 \\
\hline Eosinophils\% & 1.5 & 1.50 & 1.5 & 1.5 & 1.7 & 0.1 \\
\hline \multicolumn{7}{|l|}{ Blood Metabolites } \\
\hline $\mathrm{TP} \mathrm{g} / \mathrm{dl}$ & $6.1^{\mathrm{b}}$ & $6.3^{\mathrm{ab}}$ & $6.5^{\mathrm{a}}$ & $6.7^{\mathrm{a}}$ & $6.8^{\mathrm{a}}$ & 0.31 \\
\hline Alb g/dl & $3.5^{\mathrm{ab}}$ & $3.3^{b}$ & $3.5^{\mathrm{ab}}$ & $3.6^{\mathrm{a}}$ & $3.6^{\mathrm{a}}$ & 0.24 \\
\hline Glb g/dl & $2.6^{\mathrm{b}}$ & $3.1^{\mathrm{a}}$ & $3.1^{\mathrm{a}}$ & $3.2^{\mathrm{a}}$ & $3.2^{\mathrm{a}}$ & 0.3 \\
\hline A / G ratio & $1.33^{\mathrm{a}}$ & $1.07^{\mathrm{b}}$ & $1.14^{\mathrm{b}}$ & $1.13^{\mathrm{b}}$ & $1.14^{\mathrm{b}}$ & 0.04 \\
\hline \multicolumn{7}{|l|}{ Liver function } \\
\hline AST(U/L) & 32.7 & 31.8 & 32.2 & 31.8 & 32.5 & 0.24 \\
\hline ALT(U/L) & 20.9 & 20.9 & 19.8 & 20.9 & 21.4 & 0.29 \\
\hline \multicolumn{7}{|l|}{ Hormones } \\
\hline $\mathrm{T} 3(\mathrm{ng} / \mathrm{ml})$ & $1.4^{\mathrm{c}}$ & $1.7^{\mathrm{b}}$ & $1.7^{\mathrm{b}}$ & $2.1^{\mathrm{a}}$ & $2.3^{\mathrm{a}}$ & 0.92 \\
\hline Testosterone (ng/ml) & $5.4^{\mathrm{b}}$ & $8.3^{\mathrm{a}}$ & $8.9^{\mathrm{a}}$ & $8.2^{\mathrm{a}}$ & $9.3^{\mathrm{a}}$ & 0.3 \\
\hline \multicolumn{7}{|c|}{$\begin{array}{l}\text { a,b,c : Means within the same row with different superscripts are significantly differ.(P } \leq 0.05) \text {. } \\
\text { T1=citric }(\mathrm{Ci}) \mathrm{T} 2=\mathrm{Lactic} \text { acid }(\mathrm{La}) \mathrm{T} 3=\text { Propylene glycol }(\mathrm{Pg}) \mathrm{T} 4=\mathrm{Ci}+\mathrm{La}+\mathrm{Pg} \\
\text { *LSM: Least square means, SE: Standard error }\end{array}$} \\
\hline \multicolumn{7}{|c|}{$\begin{array}{l}\text { level in the treated rabbits' groups, as they had higher level of testosterone } \\
\text { hormone than the control group. The previous findings were in agreement with } \\
\text { Gado et al.,(2015) who reported a good relation between increased testosterone } \\
\text { hormone concentration and increase libido in male rabbits. This may be due to } \\
\text { the testosterone and estradiol, which act synergistically to stimulate male sexual } \\
\text { behaviour (Cross and Roselli, 1999). }\end{array}$} \\
\hline
\end{tabular}


IMPACTOFADDINGCITRIC,LACTICACIDS \&PROPYLENEGLYCOLONRABBITS 207

Results of semen quality characteristics (ejaculate volume, sperm cell concentration and total sperm production) are shown in Table 4. A significant increase in ejaculate volume $(\mathrm{P} \leq 0.05)$ by $26,47,38$ and $70 \%$ for groups of citric,

Table 4: LSM* $^{*}$ of sexual urge, semen characteristics, spermatozoa characteristics, daily feed intake (g) and total body gain (g) of bucks as affected by studied water supplements.

\begin{tabular}{|c|c|c|c|c|c|c|}
\hline \multirow{2}{*}{ Parameters } & \multicolumn{4}{|c|}{ Treatment groups } & \multirow[b]{2}{*}{ T4 } & \multirow{2}{*}{ S.E } \\
\hline & Control & T1 & T2 & T3 & & \\
\hline \multicolumn{7}{|l|}{ Sexual urge } \\
\hline Libido (minute) & $2.64^{\mathrm{a}}$ & $1.85^{\mathrm{b}}$ & $1.90^{\mathrm{b}}$ & $1.88^{\mathrm{b}}$ & $1.81^{\mathrm{b}}$ & 0.1 \\
\hline Reaction time (second) & $19.88^{\mathrm{a}}$ & $\begin{array}{c}19.67 \\
\mathrm{~b}\end{array}$ & $19.00^{\mathrm{b}}$ & $18.98^{\mathrm{b}}$ & $\underset{b}{18.51}$ & 0.8 \\
\hline \multicolumn{7}{|l|}{ Semen characteristics } \\
\hline Ejaculate volume (ml) & $0.34^{\mathrm{c}}$ & $0.43^{\mathrm{b}}$ & $0.50^{\mathrm{b}}$ & $0.47^{\mathrm{b}}$ & $0.58^{\mathrm{a}}$ & 0.02 \\
\hline $\begin{array}{l}\text { Sperm cell concentration } \\
\left(\mathrm{X} 10^{6} / \mathrm{ml}\right)\end{array}$ & $299.1^{c}$ & $336.4^{\mathrm{ab}}$ & $337.1^{\mathrm{ab}}$ & $322.2^{\mathrm{bc}}$ & $362.8^{\mathrm{a}}$ & 6.1 \\
\hline $\begin{array}{l}\text { Total sperm output } \\
\text { (X10\% } \% \text { ml) }\end{array}$ & $101.70^{c}$ & $144.65^{\mathrm{b}}$ & $168.55^{b}$ & $151.43^{\mathrm{b}}$ & $210.42^{\mathrm{a}}$ & 10.2 \\
\hline \multicolumn{7}{|l|}{ Spermatozoa characteristics } \\
\hline Mass motility (\%) & $2.42^{\mathrm{b}}$ & $3.88^{\mathrm{a}}$ & $3.54^{\mathrm{a}}$ & $3.43^{\mathrm{a}}$ & $4.00^{\mathrm{a}}$ & 0.1 \\
\hline Progressive motility (\%) & $30.00^{\mathrm{d}}$ & $40.00^{\mathrm{c}}$ & $46.67^{\mathrm{b}}$ & $39.58^{\mathrm{c}}$ & $55.83^{\mathrm{a}}$ & 2.4 \\
\hline Live spermatozoa (\%) & $65.96^{\mathrm{d}}$ & $69.54^{\mathrm{cd}}$ & $73.54^{\mathrm{bc}}$ & $70.25^{\mathrm{bcd}}$ & $82.42^{\mathrm{a}}$ & 1.8 \\
\hline $\begin{array}{l}\text { Abnormal spermatozoa } \\
(\%)\end{array}$ & $28.00^{\mathrm{a}}$ & $19.21^{\mathrm{cd}}$ & $19.88^{c}$ & $22.00^{\mathrm{bc}}$ & $15.83^{\mathrm{d}}$ & 1.1 \\
\hline \multicolumn{7}{|l|}{$\begin{array}{l}\text { Feed intake and weight } \\
\text { gain }\end{array}$} \\
\hline $\begin{array}{l}\text { Daily feed intake } \\
\text { (g/buck) }\end{array}$ & $139.1^{\mathrm{b}}$ & $155.6^{\mathrm{a}}$ & $160.1^{\mathrm{a}}$ & $156.6^{\mathrm{a}}$ & $164.8^{\mathrm{a}}$ & 1.8 \\
\hline $\begin{array}{l}\text { Total body gain } \\
\text { (g/buck) }\end{array}$ & $430.6^{\mathrm{b}}$ & $459.5^{\mathrm{a}}$ & $444.5^{\mathrm{a}}$ & $471.2^{\mathrm{a}}$ & $463.2^{\mathrm{a}}$ & 28 \\
\hline
\end{tabular}

a,b,c,: Means within the same row with different superscripts are significantly differ.( $\mathrm{P} \leq 0.05)$.

T1=citric (Ci) T2= Lactic acid (La) ,T3= Propylene glycol $(\mathrm{Pg}) \mathrm{T} 4=\mathrm{Ci}+\mathrm{La}+\mathrm{Pg}$

*LSM: Least square means, SE: Standard error

lactic acids, propylene glycol or mixture of them respectively, over the control group. Citric, lactic acids, propylene glycol or mixture of them resulted in a significant increase $(\mathrm{P} \leq 0.05)$ for each of sperm cell concentration and total sperm output per ejaculate compared to the control group. Moreover, the increased 
semen ejaculate volume in treated groups was correlated with significant increase in sperm cell concentration. According to Kamel et al. (2009), an increase in ejaculate volume was necessary for sperms to provide them by nutritious elements that are needed for their live. Adding organic acids or propylene glycol resulted in a significant increase $(\mathrm{P} \leq 0.05)$ in mass motility and progressive motility.

Results show a significant decrease $(\mathrm{P} \leq 0.05)$ in abnormal spermatoza in all treated groups. The percentage of abnormal sperm was significantly decreased to reach 31, 29, 21 and $43 \%$ less than the control group. These results are in agreement with Oloyede, et al., (2018) who showed that adding citric acid in the diet of the rabbit bucks supported normal growth of the reproductive tract and semen quality of the rabbit bucks. Increasing sperm cell concentration and total sperm output per ejaculate may be attributed to the organic acids or propylene glycol affects the activation of spermatogenesis in the sperm tubes to produce whole sperm.

\section{Does performance}

Does blood parameters obtained through $3^{\text {rd }}$ week of pregnancy is illustrated in Table (5). Supplementing organic acids, propylene glycol or their mixture to the drinking water, improved the immune response, as there was an increase in WBC's and lymphocytes percent. Lymphocyte percentage increased significantly $(\mathrm{P} \leq 0.05)$ in treated groups except citric acid group compared to control. The WBC's counts were within the normal range, and close results were obtained by El-kelawy et al., (2017). All hematological parameters (Ht, Hb, RBC's and WBC's) in the groups treated with individual citric, lactic acids, propylene glycol or mixture of them are illustrated in Table (5). Hematocrit (\%) level and hemoglobin concentration (g/dl) showed significant $(\mathrm{P}<0.05)$ increased in group received propylene glycol or mixture group of organic acids (citric, lactic acids) and propylene glycol compared to control group. While RBCs count significantly increased in the groups received lactic acid or mixture group of organic acids and propylene glycol compared to control group. There was no statistically significant change in WBCs count between the treated groups. These results are agreement with Kabu, et al., (2014) who reported that adding propylene glycol in dairy cattle during periparturient period had transient effects on some of hematological parameters of ruminants in the periparturient period.

Adding the mixture citric, lactic acid and propylene glycol on water of rabbits elevated serum triiodothyronine $\left(\mathrm{T}_{3}\right)$ concentration, than control group 


\section{IMPACTOF ADDINGCITRIC,LACTICACIDS \&PROPYLENEGLYCOLONRABBITS 209}

(Table 5). Triiodothyronine plays an active role in energy metabolism and metabolic rate. Any pronounced alteration in thyroid function (hyperthyroidism or hypothyroidism) is reflected in an altered metabolic rate. Indeed, the influence of

Table 5: LSM* of some blood parameters of NZW rabbits does as affected by studied water supplements.

\begin{tabular}{|c|c|c|c|c|c|c|}
\hline \multirow{2}{*}{ Parameters } & \multicolumn{5}{|c|}{ Treatment groups } & \multirow{2}{*}{ S.E } \\
\hline & Control & T1 & T2 & T3 & T4 & \\
\hline Hematocrit \% & $30.54^{\mathrm{c}}$ & $32.71^{\mathrm{b}}$ & $34.08^{\mathrm{ab}}$ & $34.83^{\mathrm{a}}$ & $34.90^{\mathrm{a}}$ & 0.3 \\
\hline Hemogloblin g/dl & $10.72^{\mathrm{c}}$ & $11.40^{\mathrm{bc}}$ & $11.88^{\mathrm{b}}$ & $12.25^{\mathrm{a}}$ & $12.39^{\mathrm{a}}$ & 0.03 \\
\hline RBCs $10^{6} / \mathrm{mm}^{3}$ & $4.11^{\mathrm{c}}$ & $4.29^{\mathrm{b}}$ & $4.41^{\mathrm{a}}$ & $4.39^{\mathrm{ab}}$ & $4.53^{\mathrm{a}}$ & 0.6 \\
\hline WBCs $10^{3} / \mathrm{mm}^{3}$ & $26.01^{\mathrm{b}}$ & $29.36^{\mathrm{a}}$ & $28.83^{\mathrm{a}}$ & $30.22^{\mathrm{a}}$ & $31.55^{\mathrm{a}}$ & 1.03 \\
\hline Lymphocytes \% & $55.43^{\mathrm{b}}$ & $56.70^{\mathrm{b}}$ & $63.45^{\mathrm{a}}$ & $64.70^{\mathrm{a}}$ & $64.62^{\mathrm{a}}$ & 1.04 \\
\hline Neutrophils & $37.62^{\mathrm{a}}$ & $38.42^{\mathrm{a}}$ & $31.86^{\mathrm{b}}$ & $29.69^{b}$ & $30.01^{\mathrm{b}}$ & 0.09 \\
\hline Monocytes & $3.54^{\mathrm{a}}$ & $2.63^{\mathrm{b}}$ & $2.30^{\mathrm{b}}$ & $2.38^{\mathrm{b}}$ & $3.14^{\mathrm{a}}$ & 0.1 \\
\hline Basophils & $1.87^{\mathrm{a}}$ & $1.61^{\mathrm{a}}$ & $1.73^{\mathrm{a}}$ & $1.59^{\mathrm{a}}$ & $1.01^{\mathrm{b}}$ & 0.11 \\
\hline Eosinophils & $1.51^{\mathrm{a}}$ & $0.73^{\mathrm{b}}$ & $1.55^{\mathrm{a}}$ & $1.50^{\mathrm{a}}$ & $1.73^{\mathrm{a}}$ & 0.1 \\
\hline \multicolumn{7}{|l|}{ Blood Metabolites } \\
\hline $\mathrm{TP} \mathrm{g} / \mathrm{dl}$ & $5.94^{\mathrm{b}}$ & $6.58^{\mathrm{a}}$ & $6.75^{\mathrm{a}}$ & $6.79^{\mathrm{a}}$ & $6.75^{\mathrm{a}}$ & 0.29 \\
\hline $\operatorname{Alb}(\mathrm{A}) \mathrm{g} / \mathrm{dl}$ & $3.30^{\mathrm{b}}$ & $3.46^{\mathrm{ab}}$ & $3.40^{\mathrm{ab}}$ & $3.60^{\mathrm{a}}$ & $3.65^{\mathrm{a}}$ & 0.22 \\
\hline $\mathrm{Glb}(\mathrm{G}) \mathrm{g} / \mathrm{dl}$ & $2.64^{\mathrm{b}}$ & $3.12^{\mathrm{ab}}$ & $3.35^{\mathrm{a}}$ & $3.19^{\mathrm{a}}$ & $3.10^{\mathrm{ab}}$ & 0.18 \\
\hline A / G ratio & $1.25^{\mathrm{a}}$ & $1.12^{\mathrm{bc}}$ & $1.01^{\mathrm{c}}$ & $1.13^{\mathrm{b}}$ & $1.18^{\mathrm{ab}}$ & 0.03 \\
\hline \multicolumn{7}{|l|}{ Liver function } \\
\hline AST(U/l) & 31.90 & 31.81 & 32.17 & 31.80 & 32.52 & 0.23 \\
\hline ALT(U/l) & 19.85 & 20.98 & 19.89 & 20.97 & 21.50 & 0.28 \\
\hline \multicolumn{7}{|l|}{ Hormones } \\
\hline $\mathrm{T}_{3}(\mathrm{ng} / \mathrm{ml})$ & $1.32^{c}$ & $1.65^{\mathrm{b}}$ & $1.63^{b}$ & $1.98^{\mathrm{a}}$ & $2.24^{\mathrm{a}}$ & 0.90 \\
\hline
\end{tabular}

serum triiodothyronine $\left(\mathrm{T}_{3}\right)$ was more pronounced with the addition of either propylene glycol or mixture of organic acids and propylene glycol followed by those received citric and lactic acids comparable to the rabbits of basal diet (Abdel-Fattah et al. 2008).

Data in Table 5 clear that treated groups significantly affected TP, Alb and Glb and recorded the best $\mathrm{A} / \mathrm{G}$ ratio. Total protein concentration increase from $5.94 \mathrm{~g} / \mathrm{dl}$ in control group to $6.79 \mathrm{~g} / \mathrm{dl}$ in group received propylene glycol in drinking water. The same increase was found for Alb $3.30 \mathrm{~g} / \mathrm{dl}$ in control group to 
$3.65 \mathrm{~g} / \mathrm{dl}$ in group received mixture of organic acids (citric and lactic) and propylene glycol. The obtained values were within the normal physiological range according to Özkan et al. (2012) who stated that TP in female rabbits ranged between 4.9-7.9 g/dl. In addition, Verag (2002) reported that Alb level in rabbits normally ranged from 2.7 to $5.0 \mathrm{~g} / \mathrm{dl}$. This suggests that increased blood protein with progression to pregnancy is a good indicator of animal health, especially the levels of Alb which reflect the animal's ability to synthesize and store proteins and acts as an index of nutritional status. (Ashour et al., 2018).

Concerning litter size results, does showed good results with supplementing individual citric, lactic acids, propylene glycol or mixture of them to drinking water, where litter size and weight at birth and at weaning were increased in treated groups compared to control group (Table 6). The findings are in harmony with Abdel-Fattah et al., (2008) found that citric acid creating acidic conditions, which increase bioavailability and absorption of nutrients and prevents the growth of harmful microorganism, which reflect on better performance. Litter size (LS) increased obviously due to supplementing any organic acids, propylene glycol or their mixture to the drinking water in treated group than that in control. These increases in LS ranged between $63 \%$ at birth to $75 \%$ at weaning in group received citric acid compared to control. It was found that increases in group received lactic acid were $60 \%$ to $72 \%$ compared to control. The improvement in the reproductive performance of preimipouros rabbits in this study may be due to the organic acids, propylene glycol or their mixture, which enhances their physiological and health characteristics, as shown by the effective function of Liver and kidneys. Lactic acid may enhance strong adjuvant effects including modulation of cell-mediated immune responses, activation of reticuloendothelial system, augmentation of cytokine pathways and regulation of interleukins Naidu et al., (2010). Propylene glycol can be converted to propionic acid in intestines are transported to the liver where it is converted to glucose, then raise energy deficit which linked to reduced lifespan of reproductive females (FortunLamothe, 2006).

The milk yields at $3^{\text {rd }}$ week of lactation increased significantly in treated groups compared to the control. The highest value in milk yield was in group four which received mixture of citric, lactic and propylene glycol. This increase may be improved the negative energy balance where, the females concurrently pregnant and lactating at the same time. The energy supplementation with glycogenic supplements as propylene glycol (PG) increase plasma glucose and 
IMPACTOFADDINGCITRIC,LACTICACIDS \&PROPYLENEGLYCOLONRABBITS 211

insulin to improve the metabolic and endocrine female status (Lorenzo, et al., 2014 and Abdel-Latif et al., 2016). There is a relation between feed intake and body gain and milk yield. The milk production increase is a response to the higher Table 6: LSM* of productive performance of NZW rabbit does as affected by studied water supplements.

\begin{tabular}{|c|c|c|c|c|c|c|}
\hline \multirow{2}{*}{ Parameters } & \multicolumn{4}{|c|}{ Treatment groups } & \multirow[b]{2}{*}{ T4 } & \multirow{2}{*}{ S.E } \\
\hline & Control & T1 & T2 & T3 & & \\
\hline \multicolumn{7}{|l|}{ Litter size at:- } \\
\hline Birth & $4.25^{\mathrm{b}}$ & $6.96^{\mathrm{a}}$ & $6.80^{\mathrm{a}}$ & $6.36^{\mathrm{a}}$ & $6.65^{\mathrm{a}}$ & 0.6 \\
\hline Weaning & $3.20^{\mathrm{b}}$ & $5.61^{\mathrm{a}}$ & $5.51^{\mathrm{a}}$ & $5.21^{\mathrm{a}}$ & $5.41^{\mathrm{a}}$ & 0.7 \\
\hline \multicolumn{7}{|l|}{ Litter weight (g) at:- } \\
\hline Birth & $242.4^{\mathrm{b}}$ & $320.0^{\mathrm{ab}}$ & $336.6^{\mathrm{a}}$ & $388.3^{\mathrm{a}}$ & $340.5^{\mathrm{a}}$ & 40.2 \\
\hline Weaning & $1128.5^{\mathrm{b}}$ & $1782.3^{\mathrm{a}}$ & $1689.2^{\mathrm{a}}$ & $1820.2^{\mathrm{a}}$ & $1780.0^{\mathrm{a}}$ & 110.3 \\
\hline \multicolumn{7}{|l|}{ Milk yield(g) at:- } \\
\hline $3^{\text {rd }}$ week & $85.2^{b}$ & $102.1^{\mathrm{a}}$ & $97.2^{\mathrm{a}}$ & $103.2^{\mathrm{a}}$ & $105.4^{\mathrm{a}}$ & 8.6 \\
\hline $4^{\text {th }}$ week & 57.1 & 62.6 & 63.2 & 61.5 & 62.0 & 4.3 \\
\hline $\begin{array}{l}\text { Daily feed intake } \\
\text { (g/doe) }\end{array}$ & $160.9^{\mathrm{b}}$ & $177.2^{\mathrm{a}}$ & $173.7^{\mathrm{a}}$ & $175.6^{\mathrm{a}}$ & $184.0^{\mathrm{a}}$ & 1.7 \\
\hline $\begin{array}{l}\text { Total body gain } \\
\text { (g/doe) }\end{array}$ & $456.5^{\mathrm{b}}$ & $484.5^{\mathrm{a}}$ & $479.2^{\mathrm{ab}}$ & $480.6^{\mathrm{a}}$ & $483.2^{\mathrm{a}}$ & 33 \\
\hline Mortality (B-W) (\%) & 24.7 & 19.4 & 19.0 & 18.1 & 18.6 & \\
\hline
\end{tabular}

a,b,c :Means within the same row with different superscripts are significantly differ.( $\mathrm{P} \leq 0.05)$.

$\mathrm{M}(\mathrm{B}-\mathrm{W})=$ Mortality from birth to weaning of kits

$\mathrm{T} 1=$ Citric $(\mathrm{Ci}) \mathrm{T} 2=$ Lactic acid $(\mathrm{La}) \mathrm{T} 3=$ Propylene glycol $(\mathrm{Pg}) \mathrm{T} 4=\mathrm{Ci}+\mathrm{La}+\mathrm{Pg}$

*LSM: Least square means, SE: Standard error

live weight and feed intake capacity of does (Xiccato et al., 2004). The supplementation of propylene glycol can rapidly supply the energy required for milk production (Lien, et.al., 2010).

Mortality rate decreased significantly compared to the control group and the lowest percentage was recorded with propylene glycol and the mixture of citric, lactic acids, propylene glycol. Similar results were obtained by El-Kelawy et al., (2001) when added $0.5 \mathrm{mg}$ propylene glycol/litter of drinking rabbit water. Also, might be due to better efficiency in feed digestion and absorption as well as reduction of dietary $\mathrm{pH}$ leads to the reduction of pathogenic microbes from gastro intestinal tract and improve nutrient absorption by rabbit (Uddin et al., 2014). A great role of propylene glycol on decreasing mortality rate and improvements in reproductive can be due partially to increasing metabolic activity and improve 
energy balance which reflect on litter size and weight at birth or at weaning and increasing the immunity as reported in other studies concerning about its effect on rabbit reproductive (Luzi et al., 2000 and Ismail et al., 2003).

Conclusively, supplementation of citric $(0.5 \mathrm{ml} / \mathrm{L})$, lactic acids $(0.5 \mathrm{ml} / \mathrm{L})$ or propylene glycol $(0.5 \mathrm{ml} / \mathrm{L})$ in drinking water for adult bucks and does can improve reproductive performance as a results role of organic additives in activation the immune system, by improving available energy, improving nutrition digestion as well as improving milk quality, and thus affecting reproduction in farm animals.

\section{REFERENCES}

Abdel-Fattah, S.A.; EI-Sanhoury, M.H.; EI-Mednay, N.M. and AbdulAzeem, F. (2008). Thyroid activity of broiler chicks fed supplemental organic acids. Inter. J. Poul. Sci., 7(3): 215-222.

Abdel-Latif,M.A.; E. S. EL-Gohary; Gabr A.A.; El-Hawary A.F.; Ahmed S.A.; Ebrahim S.A. and M. M. Fathala.(2016). Impact of Supplementing Propylene Glycol and Calcium Propionate to Primiparous Buffalo Cows During the Late Gestation and Early Lactation Period on Reproductive Performance and Metabolic Parameters. Alex. J. Vet. Sci.. 51 (1): 114-121

Ahemen,T; Abu, A.H; Orakaanya, T.T.(2013). Sperm quality and testicular morphometry of rabbits fed dietary levels of water spinach (Ipomoea aquatica) leaf meal. Agriculture and Biology Journal of North America. $4(3): 352-357$.

AOAC, (1996). Association of Official Analytical Chemists Association of Official Analytical Chemists $16^{\text {th }}$ Edn., Gaithersburd, MD, USA.

Ashour, G, (2001). Physiological adaptation of rabbits' kits to housing Conditions as related to growth. Egyptian J. Rabbit Sci., 11:115-137.

Ashour, G.; Samah M. Abdel-Rahman ; Morsy, W. A.; Noha M. AbdelAzeem and Safaa A. Barakat (2018). Physiological, reproductive and productive performance of rabbit does as influenced by n-acetylcysteine administration. Egyptian J. Rabbit Sci., 28 (1): 63-92

Ashour G.; Sedki,A. A.; Samah M. Abdel-Rahman and El-Kholy K. H. (2017). Physiological responses of rabbit does to Synertox ${ }^{\circledR}$ supplementation under different housing conditions during Summer in Egypt. Egyptian Journal of Rabbits Science, 27 (2): 377- 397. 
IMPACTOFADDINGCITRIC,LACTIC ACIDS \&PROPYLENE GLYCOLONRABBITS 213

Attia Y.A.; Kamel K.I. (2012). Semen quality, testosterone, seminal plasma biochemical and antioxidant profiles of rabbit bucks fed diets supplemented with different concentrations of soybean lecithin. Animal, 6: 824-833.

Bachman, S.E. and Mashaly,M.M. (1986). Relationship between circulating thyroid hormones and humoral immunity in immature male chickens. Dev. Comp. Immunol., 10: 395-403.

Campbell, R. C. (1956). Eosin as a stain for differentiating live and dead spermatozoa, J. Agric., Sci. 48:1-16.

Chrenková, M.L; Chrastinová, L.; Poláčiková, M.; Formelová,Z.; Baláži,A.; Ondruška, L.; Sirotkin,A. and Chrenek, P.(2012). The effect of yucca schidigera extract in diet of rabbits on nutrient digestibility and qualitative parameters in caecum. Slovak J. Anim. Sci., 45, (3): 83-88

Cross, E.; Roselli, C.E. (1999). 17 beta-estradiol rapidly facilitates chemo investigation and mounting in castrated male rats. Amer. J. Physiol., 226: 497-509.

Daader, A.H.; Gabr, H.A. and Seleem, T.S.T (1999a). Productive and reproductive performance of New-Zealand White and Californian rabbit bucks as affected by supplementing vitamin " $\mathrm{A}$ " to the diet, during summer and winter seasons. $7^{\text {th }}$ Sci. Conf. on Anim. Nutr., El-Arish, North-Sinai, Egypt, 551-564.

Daader, A.H.; Gabr, H.A. and Seleem, T.S.T. (1999b). Productive and reproductive performance of New-Zealand White and Californian rabbit bucks as affected by supplementing natural clay to the diet, during summer and winter seasons. $7^{\text {th }}$ Sci., Conf on Anim. Nutr., 19-21 October., El-Arish, North Sinai, Egypt, 565-579.

Debi M, Islam K, Akbar M, Ullha B, Das S. (2010). Response of growing rabbits to different levels of dietary citric acid. Bangladesh J Anim Sci. 2010;39(1-2):125-133.

Duncan, D.B. (1955). Multiple range test. Biometrics, 11:1-42.

El-Kelawy, H. M. ; Sedki ,A. A.; Nassrallah,M. M.; Noha, M. Abd El-Azeem. ; Samia M. Mobarez and Manal S., Mohamed (2017). Impact of adding citric, lactic acids and propylene glycol. 1. Growing rabbits performance. Egyptian J. Rabbit Sci, 27 (2): 309- 323.

El-Kelawy, H.M.; Gad Alla,S.A.; Sedki ,A.A. and Zeidan, A.B. (2001). Productive and reproductive performance of doe rabbits as affected by 
propylene glycol administration. The $2^{\text {nd }}$ Int. Conf. on Animal Prod. \& Health in Semi Arid Area, Suez Canal Univ., El-Arish, North-Sinai.

El-Kholy, K.H.M , 2003. Amelioration of heat stress on rabbits. ph,D, Thesis, Fac. Agri., Cairo, Egypt.

Fortun-Lamothe, L.(2006). Energy balance and reproductive performance in rabbit does. Animal Reproduction Science, 93:1-15

Fortun-Lamothe, L.; Prunier, A. (1999): Effects of lactation, energetic deficit and remating interval on reproductive performance of primiparous rabbit does. Anim. Prod. Sci., 55, 289-298.

Gado H.; Mellado M.; Salem A.Z.M.; Zaragoza A.; Seleem T.S.T. (2015). Semen characteristics, sexual hormones and libido of hy-plus rabbit bucks influenced by a dietary multi-enzyme additive. World Rabbit Sci. 2015, 23: 111-120

Grummer, R. R. (2008): Nutritional and management strategies for the prevention of fatty liver in dairy cattle. Vet. J. , 176: 10-20

Hinton M, Linton AH. (1988). Control of Salmonella infections in broiler chickens by the acid treatment of their feed. Veterinary Record.;123(16):416-421.

Ismail, A. M.; Sedki, A. A. and Abdallah , A. G. (2003). Influence of black seed, garlic and onion supplementation on reproductive performance and immune functions in rabbits. Egyptian J. Agric. Res., 81: 1193-1207.

Kabu, M: Civelek, T. and Birdane, F.M.(2014). Effect of born, propylene glycol and methionine administration on some hematological parameters in dairy cattle during periparturient period. Veterinarski Arhiv ., 84 (1): 19-29.

Kamel, K.I.,; Elkomy, A.E. and El-Sbeiy, M.S.,(2009). The Androgenic action of Gibberellic Acid $\left(\mathrm{GA}_{3}\right)$ on reproductive performance of New Zealand white rabbit bucks. World J. Agric. Sci., 5: 40-48.

Kishawy, T. Y. Asmaa; Amer, A. Shimaa; Osman, A.; Elsayed, A. M. Shafika; Abd El-Hack, M. E.; Swelum, A. Ayman; Awadh, H. and I. M. Saadeldin (2018). Impacts of supplementing growing rabbit diets with whey powder and citric acid on growth performance, nutrient digestibility, meat and bone analysis, and gut health. AMB Express., 8: 86

Lien,T. F.; Chang,L. B.; Horng Y. M. and Wu, C. P.(2010). Effects of Propylene Glycol on Milk Production, Serum Metabolites and Reproductive Performance during the Transition Period of Dairy Cows Asian-Aust. J. Anim. Sci., 23(3) : 372 - 378 
Lorenzo, PL ; Garcia , RM; Arias-Alvarez ,M and Rebollar ,PG( 2014). Reproductive and Nutritional Management on Ovarian Response and Embryo Quality on Rabbit Does. Reprod Domest Anim. 49 Suppl 4:4955.

Lucci, C. S.; Fonseca,L. F.; Rodrigues, P. H. M. ; Santos, M. V. and Lima, A. P.( 1998). Supplementation of propylene glycol to dairy cows in periparturient period: effects on body condition score, milk yield and first estrus postpartum. J. Dairy Sci., 81 (Suppl. 1):321

Luzi, F.; E. L. Heinzl; M. Zecchini; S. Barbieri; S. Leoni and C. Crimella (2000). Effect of propylene glycol in rabbit: Reproductive Performance. $7^{\text {th }}$ World Rabbit Congress. Valencia, Spain.

Miyoshi, S., J. L. Pate and D. L. Palmquist. 2001. Effects of propylene glycol drenching on energy balance, plasma glucose, plasma insulin, ovarian function and conception in dairy cows. Anim. Reprod. Sci., 68:29-43.

Naidu, A. S. ; Bidlack, W. R. and Clemens, R. A. ( 2010). Probiotic Spectra of Lactic Acid Bacteria. Critical Reviews in Food Science and Nutrition, .Volume 39, 13-126.

Noha,M.A.Mohamed; Faten, A.A.Ibrahim;A.A.EL-Far and A. A Sedki (2006). Effect of supplemental acidfiers on physiological and productive performance in weaning rabbits. J. Agri. Sci. Mansoura Univ., 31(2):683-690.

NRC (1977). National Research Council. Nutrient Requirements of Domestic Animal. Nutrient Requirements of Rabbits. Washington, U.S.A.

Oloyede, O.S ; Ahemen, T. and Addass, P. A.(2018). Effects of Varying Levels of Dietary Citric Acid on Semen Characteristics and Reproductive Tract Morphometry of Rabbit Bucks. Asian J Res. Anim. Vet. Sci., 2(4): 1-7

Özkan, C.; Kaya, A. and Akgül, Y. (2012). Normal values of haematological and some biochemical parameters in serum and urine of New Zealand White rabbits. World Rabbit Sci., 20: 253 - 259.

Romero C, Rebollar PG, Dal Bosco A, Castellini C, Cardinali R (2011). Dietary effect of short-chain organic acids on growth performance, mortality and development of intestinal lymphoid tissues in young nonmedicated rabbits. World Rabbit Sci ., 19(3):133-142

SAS, (2006). Statistical Analysis System. $9^{\text {th }}$ Ed. Users Guide. Static's. SAS Institute Cary, North Carolina. 
Soderstrom, J.M. 2012. Impacts of feeding a citrus extract on measures of heat stress and productive performance of high producing dairy cows during summer heat. MS thesis, University of California, Davis., USA

Szendro, Zs; K. Szendrő, and A. Dalle Zotte (2012). Management of Reproduction on Small, Medium and Large Rabbit. Asian-Australas J. Anim. Sci. May; 25(5): 738-748.

Uddin M. J.; Islam, K. M. S; Reza, A. and Chowdhury ,R. (2014). Citric acid as feed additive in diet of rabbit- effect on growth performance. $J$. Bangladesh Agril. Univ., 12(1): 87-90, 2014 ISSN 1810-3030.

Verga, M. (2002). Clinical Pathology. In: Rabbit Medicine (1st ed.). Linacre House, Jordan Hill, Oxford Ox2 8DP., pp. 140 - 164.

Xiccato G., Trocino A., Sartori A., Queaque P.I., 2004. Effect of parity order and litter weaning age on the performance and body energy balance of rabbit does. Livest. Prod. Sci., 85, 239-251.

\section{تأثثير إضافة حامض اللاكتيك والستريك والبروبلين جليكول علي:

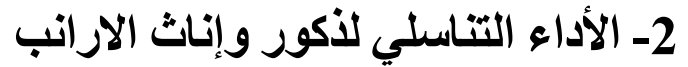

$$
\begin{aligned}
& \text { عبد المنعم صدقي، سامية مبارز، نهي محمود عبد العظيم الزئح }
\end{aligned}
$$

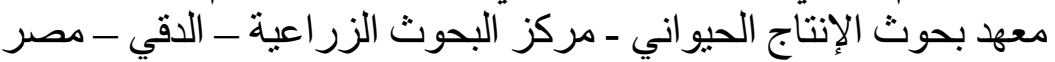

أجريت التجربة علي ذكور واناث الار انب النيوزيلندي لتحديد نأثثر إضافة حامض الإنتريك الإكي

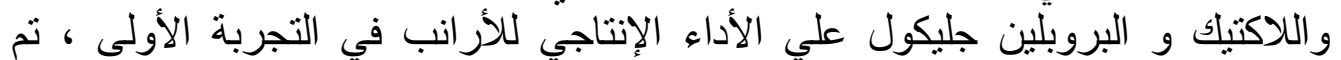

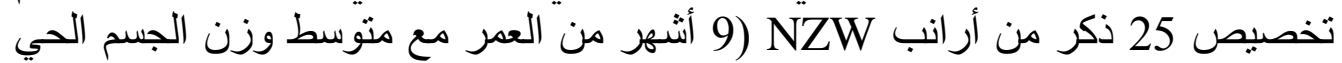

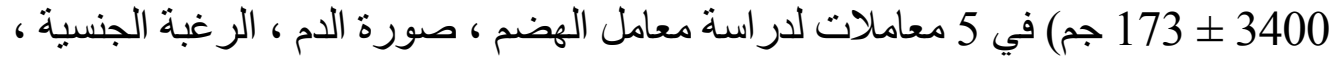

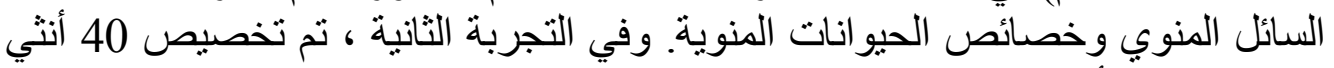

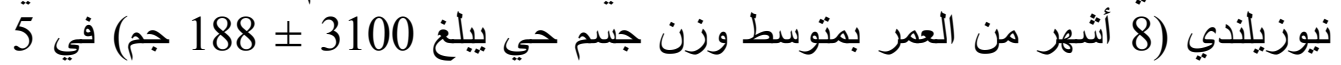

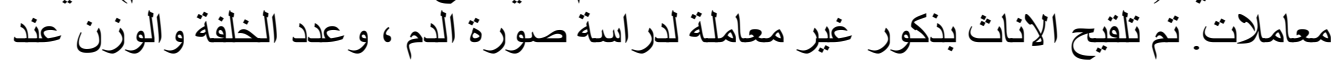

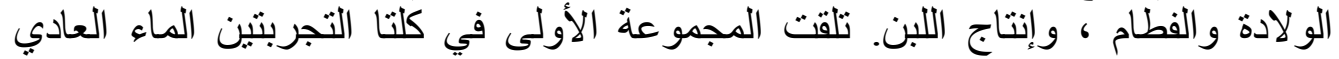
(مجموعة المقارنة)، في حين المجموعات الثانية والثالثة و الرابعة والخامسة تم إضافة الثافي الثانة 
حامض الستريك أو حمض اللاكتيك أو بروبيلين جليكول عند 0.5 مل / لتر ماء شرب وخليط منها 0.75 مل / لتر على التئ التو الي. التي.

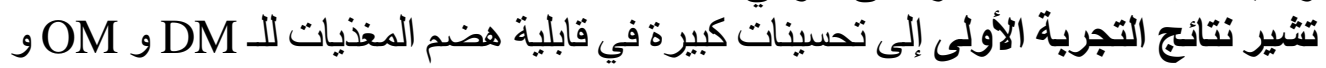
مع مجموعة الخليط من حامض الستريك وحمض اللئ اللاكتيك و البروبيلين

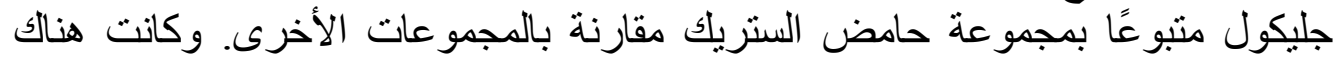

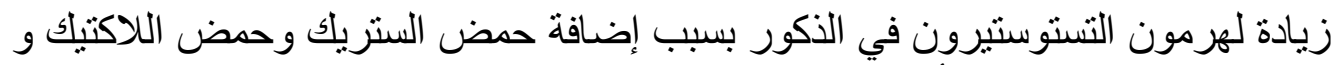

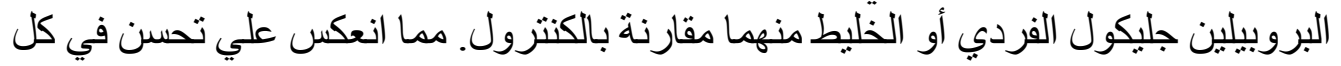

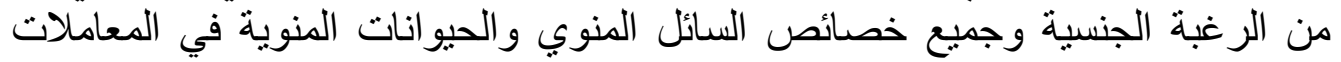

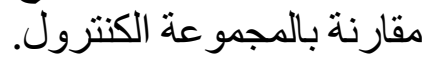

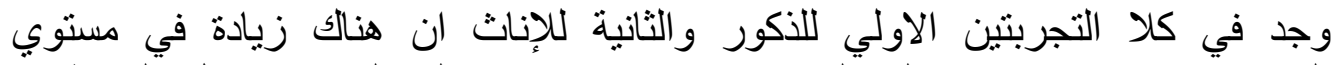

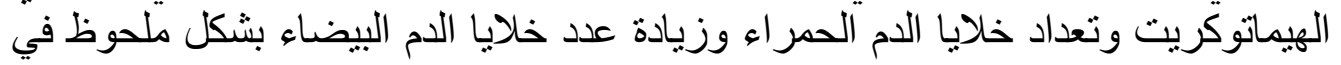

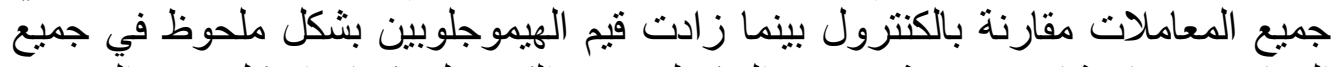

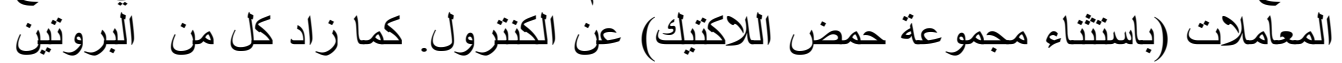

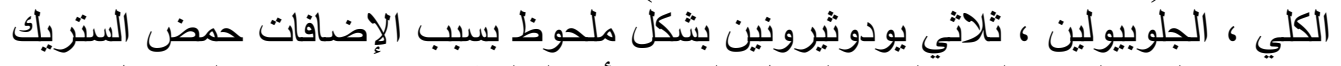

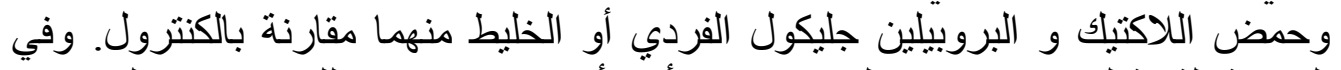

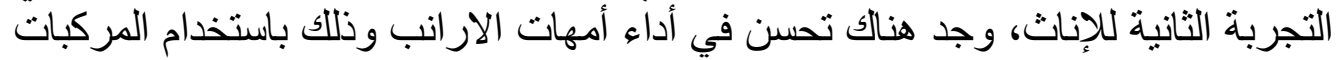

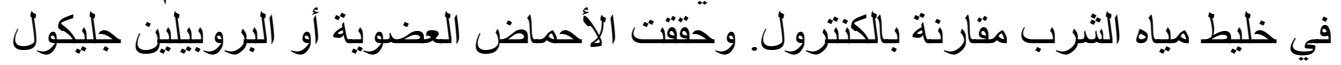

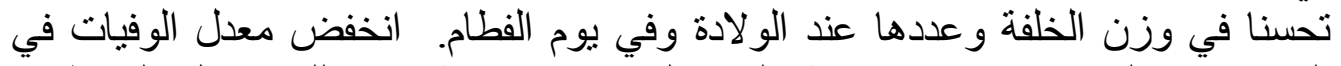

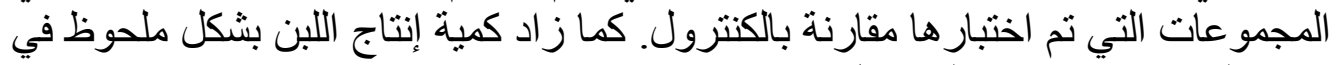

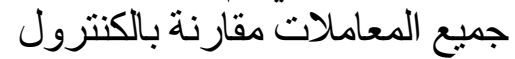
التوصية: من هذا يمكن الاستتناج أن استخدام أحماض الستريك و اللاكتيك أو البروبيلين

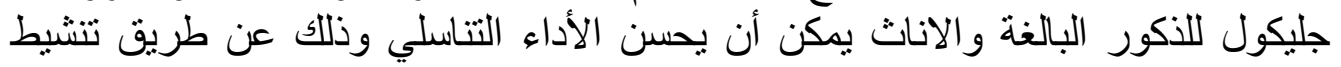

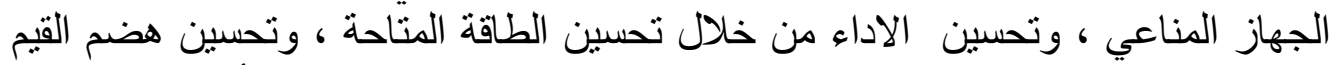
الغذائية وكذللك تحسين كمية اللبن، مما ينعكس علي حجم الخلفة وبالتالي التأثثر على التكاثر

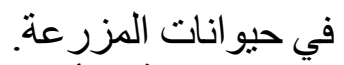
الكلمات الدالة: الأرانب ، الأداء التتاسلي ، الأحماض العضوية ، البروبيلين جليكول. 